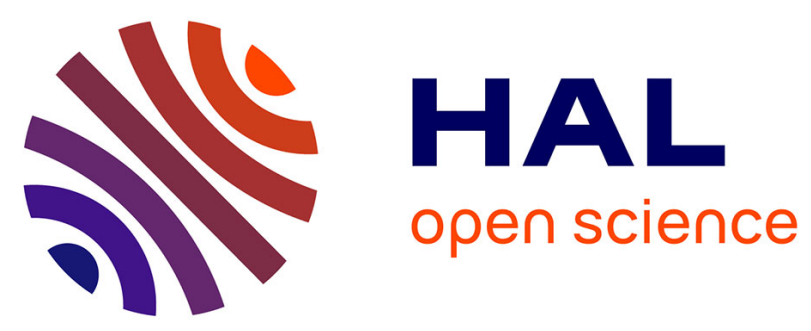

\title{
Towards a Revival of Indigenous Mobility in French Guiana? Contemporary Transformations of the Wayãpi and Teko Territories
}

Isabelle Tritsch, Cyril Marmoex, Damien Davy, Bernard Thibaut, Valéry

Gond

\section{To cite this version:}

Isabelle Tritsch, Cyril Marmoex, Damien Davy, Bernard Thibaut, Valéry Gond. Towards a Revival of Indigenous Mobility in French Guiana? Contemporary Transformations of the Wayãpi and Teko Territories. Bulletin of Latin American Research, 2015, 34 (1), pp.19-34. 10.1111/blar.12204 . hal01135244

\author{
HAL Id: hal-01135244 \\ https://hal.science/hal-01135244
}

Submitted on 17 Mar 2016

HAL is a multi-disciplinary open access archive for the deposit and dissemination of scientific research documents, whether they are published or not. The documents may come from teaching and research institutions in France or abroad, or from public or private research centers.
L'archive ouverte pluridisciplinaire HAL, est destinée au dépôt et à la diffusion de documents scientifiques de niveau recherche, publiés ou non, émanant des établissements d'enseignement et de recherche français ou étrangers, des laboratoires publics ou privés. 


\title{
Towards a Revival of Indigenous Mobility in French Guiana? Contemporary Transformations of the Wayãpi and Teko Territories
}

\author{
ISABELLE TRITSCH
}

Université des Antilles et de la Guyane, France

CYRIL MARMOEX

Independent Researcher, France

DAMIEN DAVY

Centre national de la recherche scientifique, France

BERNARD THIBAUT

Centre national de la recherche scientifique, France

\section{VALERY GOND}

Centre de coopération internationale en recherche agronomique pour le développement, France

\begin{abstract}
The goal of this article is to understand the contemporary transformations of indigenous territories in relation to several factors, including urbanisation, population growth, economic development and conservation policies. Using socio-economic, governance and land use data, we explain the current territorial reorganisations of the Wayãpi and Teko indigenous peoples. We demonstrate the existence of an emerging 'multisited' land use system that allows these indigenous peoples to benefit from resources in both urban and forest areas and ensures sovereignty over the territory. We emphasise the role of the delimitation of protected areas in catalysing identity claims and the process of land use reformulation.
\end{abstract}

Keywords: conservation policies, French Guiana, identity claims, indigenous territory, 'multi-sited' households, territorial governance.

In several Amazonian countries, indigenous communities have obtained collective land rights over their ancestral territories. However, most of these communities are now 
embedded within a broader socio-economic and institutional context in permanent evolution and are facing deep changes. The problems and opportunities exerted on their territories and their ways of life are becoming ever more diversified and involve a great variety of actors and policies interacting at multiple levels (Brondizio et al., 2009). This tends to transform indigenous territorialities and to redefine their patterns of resource use. Many studies emphasise the dynamic and adaptive nature of indigenous territorialities and identities, which are constantly adjusted according to the contexts in which the people find themselves (Alexiades, 2009). Yet the creative ability of indigenous populations to respond to the evolution of their environment is often underestimated.

Several studies have analysed the transformation of indigenous land use facing different problems and opportunities, such as population growth (McSweeney and Arps, 2005; Sirén, 2007), integration into the market (Godoy et al., 2005; Lu, 2007; Gray et al., 2008), expansion of the agricultural frontier (Hayes, 2008), urbanisation (McSweeney and Jokisch, 2007; Eloy and Le Tourneau, 2009) and changes in the land tenure regime (Freire, 2003; De Robert, 2004; Albert et al., 2011), including the overlap with conservation areas (Kent, 2008; Newing, 2009; Tritsch, 2013). These studies show that in relation to the increase of problems and opportunities affecting indigenous territories, their contemporary transformations are ever more complex and multifaceted, with a variety of adaptive responses in evidence. The drivers of these transformations not only include socio-economic and productive factors but also changes in mobility patterns, in indigenous identity and local governance. However, the ways in which all these processes come together and influence the sustainability of indigenous social and environmental systems are still poorly understood. This article examines the strategies that indigenous people develop to cope with such changes.

In this study, we focus on the Wayãpi and Teko indigenous territories in French Guiana, which lie on the border with Brazil and are now included in the French national park, the Parc Amazonien de Guyane. In recent decades, these territories have undergone major transformations (Davy et al., 2012), including urbanisation, invasions by illegal gold panners and implementation of conservation areas. Since 2007 the Wayãpi and Teko territories have been included in the Parc Amazonien de Guyane, which is based on the principle of co-management with local institutions and on the recognition of the collective land use rights of indigenous people. The creation of this park challenges our understanding of the contemporary dynamics of indigenous territories. It brings out the question of the evolution of land use practices and local governance that we define here as the way local actors interact with each other and manage the territory and its resources (Ostrom, 1990).

To explore these issues, we have created a multidisciplinary research project including local institutions, local people and anthropologists working on the region since the 1980s. Our aim is to better understand how population pressures, urbanisation, economic development and conservation policies have influenced the transformation of Wayãpi and Teko land use practices.

After considering some aspects of the study site and examining the problems and opportunities affecting the Wayãpi and Teko territories, we describe our methodological framework. We then investigate current land use changes and analyse the socioeconomic factors that influence these changes at both the household and the territorial scale. We go on to discuss the nature of multi-sited organisation in this context and explore the role of conservation policies in current land use changes and local governance. 


\section{Study Area: The Construction of the Wayãpi and Teko Territories}

This study focuses on the Wayãpi and Teko territories, located in the municipality of Camopi, in the upper and middle Oyapock River Basin, on the border with Brazil (Figure 1).

\section{The Importance of Mobility in the Wayãpi and Teko Past}

In recent centuries, the Wayãpi and Teko have undergone many territorial and adaptive changes (Grenand et al., 1999). Mobility always played a central role in their lives and in their natural resources management strategies and has been a key to their survival. Depending on their own interests and on the constraints imposed by the colonial power, they constantly changed their settlement pattern. They alternated between territorial expansion and contraction, migration and dispersion. However, their movements did not all take place at the same time, nor did they all use the same strategies. They followed either a centrifugal logic (attracted by European objects and missions) or a centripetal logic (fear of slave raids and epidemics), both of which were shaped by the network of waterways (Hurault, 1972; Grenand, 1982). The Wayãpi and Teko demonstrated their adaptive ability through the appropriation of new techniques, the alternation of alliances, wars and periods of isolation, and the occupation of new environments during their migrations. Like many Amazonian populations, the Wayãpi and Teko had a very mobile way of life. As they practised swidden agriculture, they changed the plots they cultivated each year. The location of their hamlets also changed at regular intervals to avoid over-hunting or depleting soil fertility (Grenand, 1982).

The Wayãpi and Teko people underwent a demographic collapse in the early nineteenth century. At the end of the eighteenth century, the Wayãpi were a powerful tribe, with an estimated 6,000 people, who occupied a vast territory covering approximately 15,000 square kilometres. Between 1820 and 1840, the population was reduced to less than a quarter of the earlier figure by disease, and in 1840, fewer than 1,500 Wayãpi were still alive (Grenand et al., 1999). Communities responded to epidemics by geographical dispersion and fragmentation: large areas were deserted and the habitat areas consisted of small settlements located far apart.

Mobility has therefore always, in some measure, been part of the Wayãpi and Teko way of life. At a regional level, it was a way of adapting to the effects of the European conquest and to epidemics, and at a local level, mobile lifestyles and production systems allowed them to exploit their forest environment sustainably.

\section{The Process of Integration into French Society: Settlement and Urbanisation}

For many years, the Wayãpi and Teko people were forgotten and remained isolated. It was only in 1931, when France and Brazil once again became interested in the Oyapock area, that they were 'rediscovered'. In 1947, the Wayãpi in French Guiana included only 212 people who lived in isolation in the hills of the watershed between the Oyapock and Kouc rivers (Grenand, 1982). In 1953, only 52 surviving Teko were registered scattered along the Camopi River and on the upper reaches of the 
Figure 1. The Wayãpi and Teko Territories, French Guiana.

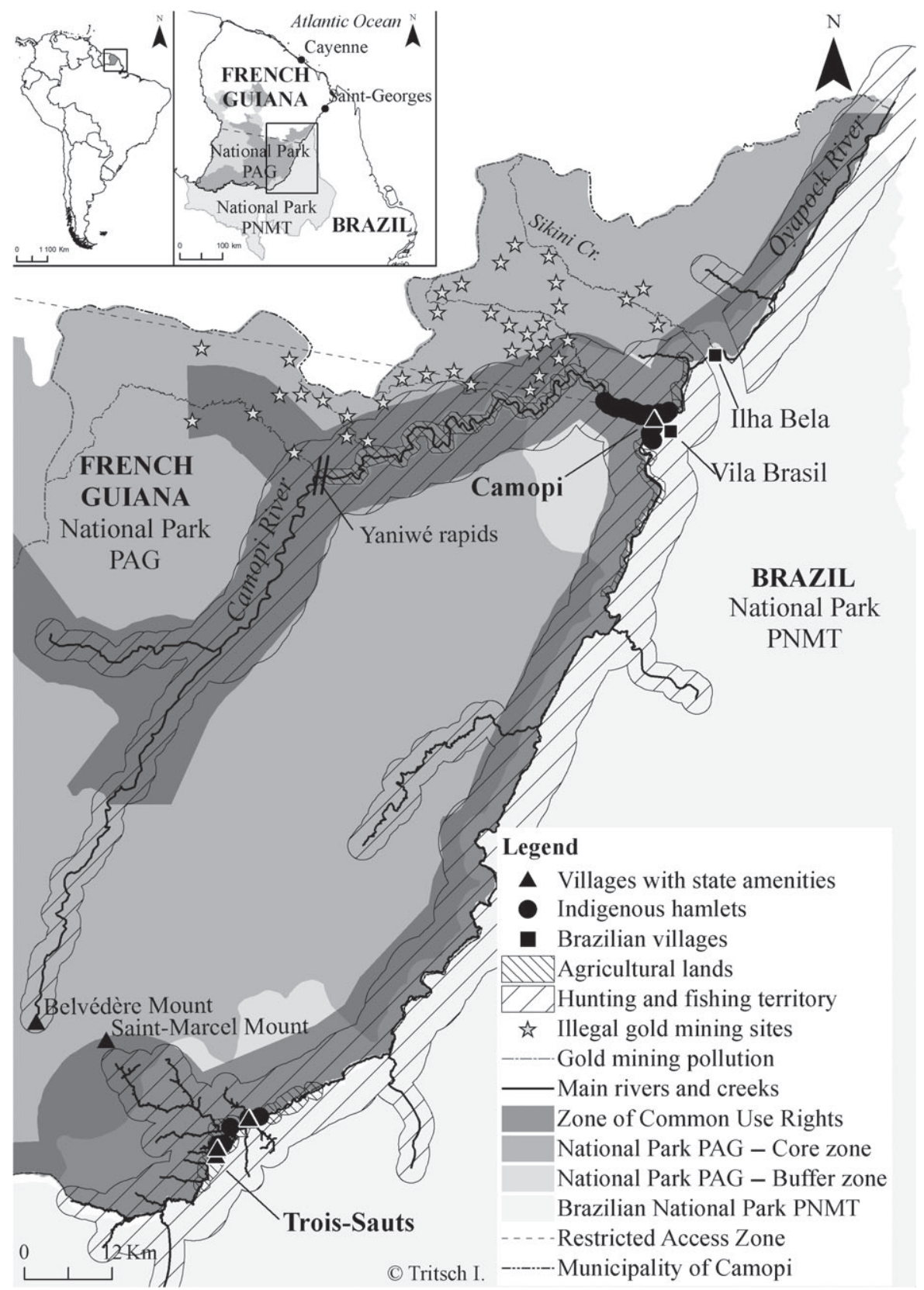


Approuague, Inini and Tampok rivers (Hurault and Frenay, 1963). Contacts with the French administration were established for access to medical care and manufactured products.

The current structure of the territory began to take shape in the mid-1950s, when the French Government opened its first offices in Camopi, including a clinic and a school; public policies aimed to settle the indigenous populations around them. The health policies had a rapid effect and from the early 1960s the population began to increase and reached more than 1,600 people in 2010 (Davy et al., 2012). The population is still growing rapidly, with an annual growth rate of 4.5 per cent between 1999 and 2009 (Tritsch, 2013). In 1969, the government gave French nationality to the Amerindian people of French Guiana and created the municipality of Camopi, which is focused on the small town of Camopi in the Middle Oyapock and on the village of Trois-Sauts in the Upper Oyapock (Figure 1). French identity papers were issued and people began to vote in national and local elections. Paid employment became available along with social benefits that led to monetisation of the local economy. Settlement around the French offices in Camopi accelerated because of the construction of social housing and electrification. From the late 1980s, Brazilian gold panners began to arrive in the region, marking the beginning of the second gold rush. Vila Brasil, a village of Brazilian traders and gold panners, was created on the Brazilian side of the Middle Oyapock, opposite Camopi (Figure 1) (Davy et al., 2012).

A few official measures aimed to guarantee specific rights to the Amerindians of French Guiana. In 1970, a prefectural decree (Arrêté préfectoral) restricted access to southern French Guiana, which is classified as a Zone d'Accès Règlementé (Restricted Access Zone; ZAR), such that administrative authorisation is required to go there. In 1987, a ministerial decree gave the native peoples of French Guiana 'Zones de Droit d'Usage Collectif' (Zones of Common Use Rights; ZDUC), where they could continue their traditional activities of hunting, fishing, gathering and agriculture. This new measure allowed the notion of common indigenous lands to take hold and it has become the basis of ongoing territorial claims (Tiouka and Karpe, 1998).

As a result of all these public policies, the Wayãpi and Teko were rapidly integrated into French society and have become sedentary. Settlement and demographic growth led to a process of urbanisation with the formation of a small town at Camopi. Thus, by 1990, the Wayãpi and Teko had, at least theoretically, embraced modernity and were 'urbanised'. In their territory, two governance systems now coexist: French institutional governance and customary governance. In the former, the main local representative is the municipal team, which has been composed of indigenous peoples since 1970 and in the latter, tacit norms and rules regulate ways of life and common land use, structured around kinship networks and reciprocity (Tritsch, 2013).

Both the Middle and Upper Oyapock areas represent a significant level of national integration, while the Upper Oyapock is more isolated: it takes one to two days in a motorised pirogue (a long and narrow canoe) to reach the town of Camopi from Trois-Sauts. This isolation is reflected in the difficulty of obtaining access to services and manufactured products, as most amenities - the town hall, police station, airstrip, postal services, and so on - are concentrated in the town of Camopi. There are no shops in Trois-Sauts. Settlement is more dispersed in the Upper Oyapock because some services, including education, are decentralised: there are three small state schools in the Upper Oyapock while there is only one in the Middle Oyapock (in the town of Camopi). The population of the Upper Oyapock is smaller, and is composed exclusively 
of Wayãpi people, whereas the Middle Oyapock area is shared between the Teko and the Wayãpi.

\section{New Territorial Issues: The Creation of Conservation Areas}

In the last decade, the Wayãpi and Teko people have been confronted with new territorial issues: the preservation of biodiversity and of the tropical rainforest. Even though these issues began to be discussed at the Rio Conference in 1992, in relation to this region, concrete measures were only taken in the 2000s, when two national parks were created. The Brazilian national park, the Parque Nacional Montanhas do Tumucumaque was created in 2002; its 3.8 million ha include all the Brazilian side of the Oyapock River. In French Guiana, the French national park, the Parc Amazonien de Guyane, was created in 2007, with 3.2 million ha covering the entire southern part of French Guiana. The park is composed of core zones, which are zones of high environmental protection, and buffer zones, which are intended to promote sustainable development (see Figure 1).

The Parc Amazonien de Guyane, is the result of a long and heated debate on park zoning, the native peoples' common resource rights, local development and the exploitation of natural resources, especially minerals (gold mining). These questions led to a confrontation between the stakeholders, all wishing to impose their own views on land use norms and standards. Indigenous peoples, initially excluded from the debate, have gradually managed to take their place in the negotiations. They have obtained the right to participate in the management of the park and a guarantee of their rights to use natural resources, even in the core zones (Aubertin and Filoche, 2011). However, there is an overlap between part of the park area and the native people's Zone of Common Use Rights. Consequently the relationship between indigenous peoples and the national park authorities remains tense.

The Parque Nacional Montanhas do Tumucumaque is a fully protected park, which theoretically excludes all use of its natural resources. With the exception of two villages of mobile gold panners and some merchants trading with them and with the indigenous communities of French Guiana, the park remains mostly uninhabited (Figure 1). However, the Wayãpi of French Guiana consider the Brazilian side of the Oyapock River as part of their ancestral territory and managed the natural resources on both sides before the park was created. Thus, the creation of the Brazilian national park has deprived the Wayãpi and Teko of part of 'their space' and part of their resources: it spatially limits their natural resource base.

Illegal gold mining is another important issue. Since 1985, several thousand illegal gold panners have arrived from Brazil and crossed the Oyapock, a border river. The Camopi River and Sikini Creek, two tributaries of the Oyapock River (both located in the Wayãpi and Teko indigenous territory) enable the illegal gold panners from Brazil to reach the main gold mining areas in French Guiana (Figure 1). The rivers provide transit routes for goods, supplies and people. There are also, as mentioned above, two gold panners' villages: Vila Brasil and Ilha Bela (Figure 1). Ilha Bela is located downstream from Camopi and is exclusively a base for illegal gold mining in French Guiana, while Vila Brasil, located just across the river from Camopi, also specialises in trading with the inhabitants of Camopi and has many shops and bars. Illegal gold mining is a source of serious pollution, mainly of the water and fishing resources, and has created an atmosphere of insecurity. This is the main environmental threat in the Wayãpi and Teko 
territories and in the French national park. It creates many cross-border tensions and conflicts (Davy et al., 2012).

\section{Methods and Data}

We used a combination of multidisciplinary - mainly anthropological and geographical - field surveys and remote sensing to investigate the contemporary transformations of the territory and the ways people are coping with and adapting to their changing environment.

Data were collected in surveys conducted between 2009 and 2012 among all the Wayãpi and Teko inhabitants of the municipality of Camopi: 258 households, with 1,604 members. Questionnaires were conducted in the respondent's household. Questions dealt with household composition, economic activities, resource use, mobility patterns, and the norms and rules that shape land use and perceptions of local governance, especially in relation to the creation of the national parks. Not all the questions were asked at the same time, and most households were visited several times during our project. It was possible to build a relationship of trust with respondents because some of the researchers in our team had been involved for more than 30 years with the Wayãpi and Teko communities and because one member had written a $\mathrm{PhD}$ thesis on their land use practices (Tritsch, 2013).

We also carried out participatory mapping of the fields and fallows of each household, using aerial photography (BdOrtho IGN). When possible, we went to the fields with the families and so 598 swidden fields were visited and geo-referenced with GPS points. Simultaneously, land cover maps of the Wayãpi and Teko territories were made using 1989, 2002, 2009 and 2010 LANDSAT and SPOT satellite images with a resolution of respectively 30 and 20 metres.

The different forms of land cover were characterised using our GPS points. We used information from ground truthing in a sample area to classify the land use in the whole of the Wayãpi and Teko territories. This supervised classification using sample areas correctly distinguished between new fields (recently burned), cultivated fields, fallows (up to fifteen years' old), and old forest. The data were transferred into a geographic information system and we made diachronic analysis of land use changes between 1989 and 2010, exploring the evolution of the length of fallow and of the spatial distribution of the swidden plots over time.

A geo-database was then built to link household data and spatial data. Socioeconomic and productive variables were calculated for each household with the aim of analysing the correlation between socio-economic factors and land use behaviour. These variables and their descriptive statistics are listed in Table 1. The qualitative data on perceptions of local governance were used to complete the interpretation of the current land use dynamics.

As land use is structured around rivers (the main transport network), which are not linear because of meandering, Euclidean distances misrepresent land use. For this reason, we used ArcGIS software to calculate cost-distances, which are relative measures of the cost of travelling under different surface conditions. The cost-distance represents the lowest cumulative 'cost' in minutes (or to put it simply, the minimum travel time) required to get from one point to another as people move by pirogue on the rivers or on foot in the forest. 
Table 1. Descriptive Socio-Economic and Productive Variables of Households and Land Use in the Municipality of Camopi (2009-2010)

\begin{tabular}{|c|c|c|c|c|c|}
\hline $\begin{array}{l}\text { Households' socio-economic and productive } \\
\text { descriptive variables - household scale }\end{array}$ & $N$ & Mean & SD & Min. & Max. \\
\hline Age: Age of household head & 256 & 40 & 13 & 15 & 81 \\
\hline Nbp: Number of persons in household & 257 & 6 & 3 & 1 & 16 \\
\hline Income: Monthly household income (euros) & 257 & 2081 & 916 & 475 & 6514 \\
\hline $\begin{array}{l}\text { Size_tot: Household's total area slashed and } \\
\text { burned in one year (hectare) }\end{array}$ & 119 & 0.6 & 0.3 & 0.1 & 1.9 \\
\hline $\begin{array}{l}\text { CstDist_Res_Agri: Travel time between } \\
\text { household's place of residence and its farthest } \\
\text { agricultural plot (minutes) }\end{array}$ & 229 & 31 & 31 & 0 & 231 \\
\hline $\begin{array}{l}\text { CstDist_ResInfra: Travel time between } \\
\text { household's place of residence and nearest area } \\
\text { equipped with stateamenities (minutes) }\end{array}$ & 257 & 5 & 7 & 0 & 27 \\
\hline
\end{tabular}

\begin{tabular}{lccr}
\hline Households' descriptive qualitative variables & N & Category & $\%$ \\
\hline Job: Employment of at least one member of the household & 257 & Yes & 30 \\
& & No & 70 \\
\hline
\end{tabular}

\begin{tabular}{lccccc}
\hline Land use descriptive variables - territory scale & N & Mean & SD & Min & Max \\
\hline $\begin{array}{l}\text { CstDist_Infra: } \text { Travel time between agricultural } \\
\text { plot and nearest area equipped with state }\end{array}$ & 305 & 27 & 29 & 0 & 264 \\
$\begin{array}{l}\text { amenities (minutes) } \\
\text { Area: Agricultural plot area (hectares) }\end{array}$ & 305 & 0.5 & 0.3 & 0.1 & 1.4 \\
\hline
\end{tabular}

${ }^{a}$ The areas equipped with state amenities are the town of Camopi in the Middle Oyapock and the villages of Zidock, Roger and Yawapa in the Upper Oyapock.

\section{Results: Land Use Changes and the Role of Households' Socio-Economic Characteristics}

Cassava (Manihot esculenta) and other cultivated plants are still the most common food of the Wayãpi and Teko, combined with game, fish and wild fruits. Swidden agriculture, hunting, fishing and gathering remain subsistence activities, with no trade and no use of external inputs. Even if the money contributed by wage labourers and social grants plays a significant role in the household economy, the products of subsistence activities remain essential. The agricultural plots are small, 0.5 hectares on average (Table 1 ).

However the growth and settlement of the population have reduced access to the forest resources needed to practise swidden agriculture. The diachronic analyses of land cover and our surveys shows that the length of fallow has been reduced in the vicinity of the town of Camopi, leading to soil depletion, the need for increased weeding because of the proliferation of weed species, and a reduction in the number of cultivated species. In addition, the travel time needed to reach the agricultural plots has increased (Tritsch et al., 2012). While the Wayãpi and the Teko have generally considered the forest resources to be abundant (Grenand, 1992), the perception of their scarcity around town has led to the appearance of signs of land ownership: a family may decide to open an 
Table 2. Bivariate Relationships between Household Socio-Economic and Production Variables using Mann-Whitney and Spearman's Rank Correlation Coefficient

\begin{tabular}{llccc}
\hline & & CstDist_ResInfra & CstDist_ResAgri & Income \\
\hline \multirow{2}{*}{ Age } & $N$ & 256 & 229 & 256 \\
& Spearman's rho & -0.1108 & 0.0320 & $0.3106^{* * *}$ \\
& Significance & 0.0768 & 0.6304 & $<0.0001$ \\
& $N$ & 257 & 229 & 257 \\
& Spearman's rho & -0.0976 & $0.1581^{*}$ & $0.7854^{* * *}$ \\
& Significance & 0.1186 & 0.0167 & $<0.0001$ \\
& $N$ & 257 & 229 & - \\
\multirow{5}{*}{ Size_tot $t$ tome } & Spearman's rho & -0.0701 & $0.1479^{*}$ & - \\
& Significance & 0.2629 & 0.0252 & - \\
& Spearman's rho & 191 & 191 & - \\
& Significance & 0.0825 & $0.3227^{* * *}$ & - \\
& $N$ & 0.2565 & $<0.0001$ & - \\
& Mann-Whitney's coefficient & 257 & 229 & - \\
& Significance & 6376 & 5651.5 & - \\
\hline
\end{tabular}

Key. Age: age of household head; Nbp: number of persons in household; Income: monthly household income (euros); Size_tot: total area household prepares for cultivation by slash-and-burn each year (hectares); Job: households with at least one member in employment; CstDist_ResInfra: travel time between household's place of residence and nearest area with state amenities (minutes);

CstDist_ResAgri: travel time between household's place of residence and most distant agricultural plot (minutes).

$* *$ Correlation significant at 0.001 level. "Correlation significant at 0.05 level.

agricultural plot at a particular time because if they do not, another family will. The same phenomenon has been observed in other areas with population densification and the settlement of indigenous populations (Sirén, 2007). For these reasons, densification and settlement places strong constraints on Wayãpi and Teko land use.

In response to this, land use began to change dramatically in the 1990s. The densification described above has been followed by a tendency to residential dispersal. In 2010, 48 separate places of residence were identified, while fifteen years ago, there were less than twenty. Indigenous people have created new hamlets along the river, at a distance of between 0.5 and 8 kilometres from the town, or about half an hour at most by pirogue, and established permanent residence in these hamlets (Table 1). Nowadays only 26 per cent of the Wayãpi and Teko in the Middle Oyapock live in the town of Camopi.

Life in these new hamlets allows the inhabitants to focus on the family and a more traditional way of life. The peace and tranquillity of life in a hamlet with only family members for company, combined with easier access to natural resources, are the main reasons people gave us for leaving the town and establishing a new hamlet. As shown in Table 2, the dispersion of residence sites in relation to state amenities affects all household categories, with no distinction based on the age of the household head (the one who has authority to exercise family control), income, the number of household members or their employment status.

Resource management areas are also increasingly dispersed, with new agricultural lands being opened up at greater and greater distances from the town of Camopi and the Upper Oyapock villages (up to four and a half hours away by pirogue in 2009) (Table 1). Swidden plots opened up in distant areas are significantly larger than those 
located near the areas equipped with state amenities (Area vs. CstDist_Infra, $\mathrm{N}=305$, $\mathrm{S}=3,409,749, p<0.001$ ) and involve the slashing of old fallows or primary forest. The decision to cultivate more distant areas reflects the greater ease of access to forest resources far from the town and villages. They allow more sustainable exploitation of the natural resources by spreading the demographic pressure on these resources over a wider area.

These distant agricultural lands are organised according to family networks: relatives open lands for cultivation in similar areas, making it possible to share labour as well as the cost of transport. The plots are organised around swidden farm houses, which become a second territorial anchorage for extended families, occupied at different times for several weeks at a time, according to the agricultural calendar and the timing of school terms and holidays. The dispersed swidden farm houses provide better access to natural resources, while the main residence continues to be located in the town and main villages as a way for the household to access state amenities and services.

Having homes at different locations enables households to sustain extensive agricultural systems. Most households open at least two agricultural plots each year: a small one, close to their main place of residence, managed with a short rotation period and chiefly used as a local food supply, and another, located at a greater distance from the areas equipped with state amenities, managed on the basis of long fallow. These distant agricultural plots serve a number of different functions: people go there on weekends and on school holidays, taking the opportunity to go hunting and fishing with the family. These places also play a fundamental role in the transmission of intergenerational ethno-ecological knowledge. This 'multi-locality' of productive and residential places is possible because of the flexibility of swidden agriculture (Dounias et al., 2000; Eloy, 2005), which allows people not to visit their fields for several weeks or even months at a time. Hunting territories are also very extensive. Many hunting camps are scattered along the rivers, enabling the population to organise hunting expeditions taking them away from the villages for more than four days, travelling by pirogue.

Whether or not a household opts for multi-locality is influenced by several socioeconomic and production characteristics. Households with a large number of mouths to feed tend to travel longer time-distances between their home and their most distant agricultural plot and to cultivate larger plots (Table 2). Monetary income also influences a household's choices: travel time between the household's place of residence and their most distant agricultural plot is correlated with income (Table 2). This is because of the high cost of travel by pirogue, mainly the cost of fuel. A household's monetary income is strongly correlated with the number of people in the household thanks to social benefits (Table 2). For these reasons, young households generally have less money (Table 2); but support and redistribution within networks based on kinship remain valued social practices, which can help defray transport costs. As a result, even young households use resource management systems based on multi-locality and do not hesitate to travel long distances by pirogue to reach their agricultural plot (Table 2).

Employment status did not influence land use strategies: neither the size of the agricultural plot nor the distance travelled to reach the most distant agricultural plot was correlated with having a job (Table 2). In fact, the cultivation of cassava, in addition to its nutritional importance, continues to have a strong cultural significance, mainly the production of cachiri manioc beer, which still represents a social bond in both Wayãpi and Teko society (Davy et al., 2012). For this reason, swidden agriculture is still practised, even by households with one or more members who have a job and/or a high income, which means they could buy food instead of producing it themselves. 
However, people with jobs have less time to devote to agriculture and frequently tend to pay outsiders to do agricultural work (a service provided by Brazilian people in Vila Brasil).

\section{Discussion}

\section{Multi-Sited Households: A Resource Management Strategy}

After decades of concentration and settlement in and around town or large villages to enable access to state services such as health and education, the land use systems of the Wayãpi and Teko today are based on the revival of household mobility and their maintaining several complementary locations of resource use (Tritsch et al., 2012). Households seek to optimise their land use in order to benefit from the amenities available in larger villages while maintaining traditional extensive subsistence activities such as swidden agriculture. Their main territorial strategy is multi-locality, characterised by multi-sited residential and production systems linked by high mobility patterns. Cash income from wage labour and welfare plays a crucial role in these processes: the money is invested in transport, enabling households to extend their swidden area and residential locations. This monetary resource, often seen as creating acculturation and dependence on a globalised lifestyle, allows the Wayãpi and Teko to adjust their resource management strategies and to reconnect with indigenous mobility.

In one way or another, the traditional cyclical displacement of villages has been replaced by multi-sited organisation and very frequent functional mobility so as to be able to incorporate the benefits of the town into local production systems. Setting up a main residence in or around a larger village or town does not affect people's individual and functional mobility; on the contrary, it may even increase it (Kelly, 1992). These phenomena are similar to those observed by Eloy (2008) in the peri-urban region of São Gabriel da Cachoeira (Upper Rio Negro, Brazil). Eloy emphasises the importance of the spatial and temporal diversification of production systems and the role of the family's circular mobility in bringing about change in indigenous land use systems.

Similar processes of dispersal of housing and production systems after several decades of residential settlement around Western amenities are also emerging to increase access to forest resources in other indigenous territories, such as the Wayãpi indigenous land in Brazil's Amapá state (Tilkin Gallois, 2004; Tritsch, 2013) and the Auaris region in Venezuela (Le Tourneau, 2008).

However, population growth, urbanisation and the constraints on the availability of natural resources around towns and large villages are not the only drivers of these changing patterns of land use. Our surveys show that local dynamics of identity re-affirmation and territorial re-appropriation also play a very important role. The implementation of conservation policies has caused governance conflicts associated with the overlapping of different territorial zones. These overlaps create jurisdictional problems because they leave the legal status of these areas unclear. They involve different actors, mainly customary representatives, municipal administrations, the Guyanese prefecture and the local delegation of the French national park authorities. All have different views, interpretations and objectives concerning forms of natural resource use and regulation, based on either scientific or traditional ecological knowledge or on strict application of French and European regulation. Historically, the Wayãpi and Teko did not develop formal governing structures or land use rules for their 'Zone of Common 
Use Rights'; instead, they managed it under a tacitly understood set of customary norms. Thus, the overlap of the flexible and unformulated customary rules of the 'Zone of Common Use Rights' with the formal rules of the French national park has complicated understanding of the customary territory and of local governance.

Given this background of existing tensions, the question of the land tenure regime and natural resource use becomes a very sensitive issue. Hamlets, swidden farm houses, hunting camps and the distant agricultural plots are seen as markers of land occupation and appropriation. The extension of land use systems aims to re-occupy and re-appropriate part of the ancestral territory. It is part of a broader process of identity re-affirmation. Former hamlets, i.e. those occupied before settlement around state amenities in the 1970 s, play an important role in this process. They encourage some kinship groups to establish a swidden farm house or hunting camp close to where these hamlets were located.

The French national park has become a controversial actor. Although the park statutes recognise permanent and exclusive rights over natural resources for native people in its core zone, the power of park authorities in the local area is a matter of concern. The park authorities are very influential actors, with several intertwined levels of decision-making, and the park provides many local jobs and has substantial financial resources compared to those of municipal authorities, causing conflicts of interest (Tritsch, 2013).

The Teko, whose hunting areas partly overlap with the core zone of the French national park, attach great importance to the issue of natural resource management. For them, the 'protected area' notices at the entrance of the park's core zone on the Camopi River, which do not mention that this area is also the Teko 'Zone of Common Use Rights', are considered to represent a form of stranglehold on their territory by the park authorities. In response to this pressure on land tenure, they have adapted their natural resource management practices by considerably extending their swidden agricultural lands in an act of defiance with the park. Thus, in 2010, the most distant Teko agricultural plots were located six hours by motorised pirogue (more than 70 kilometres on the river) from the town of Camopi, just downstream from the Saut Yaniwe rapids and the national park's core zone (Figure 1). Explanations given by members of the Teko community for the extension of agricultural lands in these remote areas explicitly emphasised marking their sovereignty over land and resources in relation to the national park. These explanations are also strongly influenced by identity re-affirmation: 'This is Teko land'.

As far as land tenure is concerned, this process of identity and territorial reaffirmation is shared by the Wayãpi and the Teko: the land of the Wayãpi, the land of the Teko, is used as a generic identity to differentiate themselves from 'The Other' (Tilkin Gallois, 2004). The juxtaposition of territory and identity is re-valued and used to redefine a specific community space that is 'both functional and symbolic, where over the years, practices and a collective memory have created a differentiated sense of "Us" as well as a sense of belonging' (Jolivet and Léna, 2000: 8). The exogenous definition of the boundaries of the new protected areas encourages local people to rethink and readjust their ways of relating to land, and they re-fuel claims of ethnic, cultural or social singularity (De Robert, 2004). They (re)construct a collective history and identity associated with the territory.

Identity and territorial claims are whetted by the presence of the Brazilian base for illegal gold mining at Ilha Bela and the many Brazilian gold panners' pirogues travelling up the Camopi River, in an area that is part of both Teko territory and of the French national park's core zone. In fact, all the conservation policies in place are not enough 
to curb the social and environmental disaster caused by illegal gold mining. A sense of injustice therefore prevails among the Wayãpi and the Teko: illegal Brazilian gold panners settle in their territory and in the French national park's core zone, but French Amerindian are prevented from hunting or pursuing swidden farming in the Brazilian national park in the name of nature preservation. The diachronic analyses of land cover show that in 2002, before the creation of the Brazilian national park, the Wayãpi used to open about half of their swidden fields on the Brazilian side of the Oyapock River. In 2010, this proportion fell to 20 per cent around Trois-Sauts and only 5 per cent around Camopi. Indeed, the Wayãpi and Teko, who tend to be very legalistic, define themselves as Amerindians and as French citizens. They consider the Oyapock Brazilian side as part of their ancestral territory, which they have managed until now, but they are also aware that the area belongs to Brazil, with its own laws. For that reason, while they may be willing to stop opening fields on the Brazilian side and to accept confiscation of their ancestral lands on that side, they draw the line, in return, at being invaded by Brazilian gold panners. This contradictory situation undermines cross-border relations and the possibility of protecting the environment . The French national park suffers directly from the lack of coherence of the French policy against illegal gold mining, such as the absence of policy coordination between France and Brazil to combat illegal mining in the area.

In addition, the Wayãpi and Teko are currently witnessing an increase in the geopolitical importance accorded to the French-Brazilian border. In 2005, a Brazilian military police base was built just downstream from Camopi and Vila Brasil, with the stated aim of improving border control. The creation of the Brazilian national park and the increased military presence in the region reflect the Brazilian political wish to populate and control its northern border, to ensure and assert its national sovereignty (Boudoux d'Hautefeuille, 2012). In addition to its importance within Brazilian environmental policies, given its status as one of the largest continuous areas of protected tropical forest, the Brazilian national park is, then, also part of a geopolitical strategy for the Brazilian border region. The territory of the Wayãpi and Teko, which, until recently, was still considered a marginal border area, thus finds itself in the middle of two different conservation policies and the geopolitical interests of both France and Brazil.

Thus, for the past ten years, pressure on the Wayãpi and Teko territories has increased and become more complex as a result, in part, of the creation of new conservation areas but also to its cross-border location and to continuing invasion by illegal gold panners. This leads to governance conflicts and, together with population growth, encourages new forms of local social organisation, identity affirmation and territorial re-appropriation that intensify the reorganisation of land use (Torre and Zuindeau, 2009). A new form of territorial governance has emerged with a resource use system based on multi-sited households. In this way, the Wayãpi and Teko assert their customary authority and rights over natural resources, while adapting their natural resource management strategies to the process of urbanisation.

\section{Conclusion}

We have emphasised the revival of indigenous people's mobility and the complementarity of town and forest territoriality. Residential settlement around small towns or large villages, ensuring access to national amenities and services, no longer represents the 
spatial limit of indigenous land use systems. Instead, the flow of monetary resources, associated with their redistribution through kinship networks, overcomes transport problems and enables ever greater mobility and occupation of more remote territories. With their multi-sited land use system, indigenous people interact with urban and forest environments, which are not seen as opposing but complementary, and, in so doing, demonstrate the flexibility of their land use systems and the importance of their claim for identity and struggle for land. Therefore, the current territorial and social reorganisation of indigenous land use underlines their adaptability and the importance of the interplay between processes such as mobility and settlement, dispersion and concentration.

This study also highlights the importance of conservation policies, combined with other contemporary territorial changes, in transforming the land use systems of indigenous people. The delimitation of new protected areas and overlapping jurisdictions, together with local forms of resource use and with rights to and regulation of natural resources, underline the importance of indigenous land rights and reinforce their identity and territorial claims. Confrontation with different institutional actors and different views about natural resource management encourages local people to change their land use strategies. The proliferation of hamlets, swidden farm houses, hunting camps and distant swidden plots are intended to be a sign of their land occupation and appropriation. In other words, the implementation of conservation policies seams to act, paradoxically, as a catalyst for further territorial and identity re-appropriation. Indigenous people are adapting their territorial governance system and seeking to reinforce their customary authority and rights over natural resources by extending their occupation of the territory. For this reason, by articulating urban and forest territorialities, multi-sited households can better ensure sovereignty over a large collective territory. Further research is needed to analyse the impacts of environmental policies' implementation on indigenous governance and territorialities such as multi-locality.

\section{Acknowledgements}

We warmly thank the Wayãpi and Teko people for taking part in this study and we also acknowledge the contribution of all our partners, especially the municipality of Camopi, the Parc Amazonien de Guyane, the Observatoire Hommes-Milieux 'Oyapock', the Centre de coopération internationale en recherche agronomique pour le développement and the Fonds social européen. We are grateful to the 'Surveillance de l'Environnement Amazonien par Satellite' and 'Initiative for Space Innovative Standards' programmes for providing the satellite imagery.

\section{References}

Albert, B., Robert, P., Laques, A. E. and Le Tourneau, F. M. (2011) 'From Amerindian Territorialities to "Indigenous Lands" in the Brazilian Amazon: The Yanomami and Kayapo Cases' in C. Aubertin and E. Rodary (eds.) Protected Areas, Sustainable Land? Ashgate: Marseille, 123-141.

Alexiades, M. N. (2009) 'Mobility and Migration in Indigenous Amazonia: Contemporary Ethnoecological Perspectives - An Introduction' in M. N. Alexiades (ed.) Mobility and Migration in Indigenous Amazonia: Contemporary Ethnoecological Perspectives, Studies in Environmental Anthropology and Ethnobiology. Berghahn Books: Oxford, 1-43. 
Aubertin, C. and Filoche, G. (2011) 'Creation of the Guyana Amazonia Park: Redistribution of Powers, Local Embodiment and Territorial Divisions' in C. Aubertin and E. Rodary (eds.) Protected Areas, Sustainable Land? Ashgate: Marseille, 105-121.

Boudoux d'Hautefeuille, M. (2012) Entre marge et interface, recompositions territoriales à la frontière franco-brésilienne (Guyane/Amapá). Doctoral thesis, Université des Antilles et de la Guyane, Cayenne, France.

Brondizio, E. S., Ostrom, E. and Young, O. R. (2009) 'Connectivity and the Governance of Multilevel Social-Ecological Systems: The Role of Social Capital'. Annual Review of Environment and Resources 34: 253-278.

Davy, D., Tritsch, I. and Grenand, P. (2012) 'Construction et restructuration territoriale chez les Wayãpi et Teko de la commune de Camopi, Guyane française'. Confins 16. [WWW document]. URL http://confins.revues.org/7964 [accessed 7 March 2013].

De Robert, P. (2004) 'Terre coupée. Recomposition des territorialités indigènes dans une réserve d'Amazonie'. Ethnologie Française 34(1): 79-88.

Dounias, E., Tserikiantz, F., Carrière, S., McKey, D., Grenand, F., Kocher-Schmid, C. and Bahuchet, S. (2000) 'La diversité des agricultures itinérantes sur brûlis' in S. Bahuchet (ed.) Les peuples des forêts tropicales aujourd'hui: 2. Une approche thématique. APFT: Bruxelles, 65-105.

Eloy, L. (2005) Entre ville et forêt: le futur de l'agriculture amérindienne en question Transformations agraires en périphérie de São Gabriel da Cachoeira, Nord-ouest amazonien, Brésil. Doctoral thesis, Université Paris III, Paris.

Eloy, L. (2008) 'Dynamiques et adaptation des systèmes agroforestiers périurbains dans le nord-ouest Amazonien'. Bois et Forêts des Tropiques 296(2): 45-54.

Eloy, L. and Le Tourneau, F.-M. (2009) 'L'urbanisation provoque-t-elle la déforestation en Amazonie? Innovations territoriales et agricoles dans le nord-ouest Amazonien (Brésil)'. Annales de Géographie 667(3): 204-227.

Freire, G. (2003) 'Tradition, Change and Land Rights Land Use and Territorial Strategies Among the Piaroa'. Critique of Anthropology 23(4): 349-372.

Godoy, R., Reyes-Garcia, V., Byron, E., Leonard, W. and Vadez, V. (2005) 'The Effect of Market Economies on the Well-Being of Indigenous Peoples and on their Use of Renewable Natural Resources'. Annual Review of Anthropology 34: 121-138.

Gray, C., Bilsborrow, R., Bremner, J. and Lu, F. (2008) 'Indigenous Land Use in the Ecuadorian Amazon: A Cross-cultural and Multilevel Analysis'. Human Ecology 36(1): 97-109.

Grenand, P. (1982) Ainsi parlaient nos ancêtres: essai d'ethnohistoire Wayãpi, Travaux et documents de l'ORSTOM. ORSTOM: Paris.

Grenand, P. (1992) 'The Use and Cultural Significance of the Secondary Forest Among the Wayapi Indians' in M. Plotkin and L. Famolare (eds.) Sustainable Harvest and Marketing of Rain Forest Products. Island Press: Washington, 27-40.

Grenand, P., Grenand, F. and Ouhoud-Renoux, F. (1999) 'Entre fleuve et forêt: stratégies adaptatives du peuplement Wayãpi depuis le 18e siècle' in S. Bahuchet, D. Bley, H. Pagezy and N. Vernazza-Licht (eds.) L'homme et la forêt tropicale, Travaux de la société d'ecologie humaine. Editions de Bergier: Châteauneuf-de-Grasse, 223-235.

Hayes, T. M. (2008) 'The Robustness of Indigenous Common-property Systems to Frontier Expansion: Institutional Interplay in the Mosquitia Forest Corridor'. Conservation and Society 6(2): 117-129.

Hurault, J.-M. (1972) Français et Indiens en Guyane, 1604-1972. UGE: Paris.

Hurault, J.-M. and Frenay, P. (1963) 'Les Indiens Emerillon de la Guyane française'. Journal de la Société des Américanistes 52: 133-156.

Jolivet, M.-J. and Léna, P. (2000) 'Des territoires aux identités' in M. J. Jolivet (ed.) Logiques identitaires, logiques territoriales, Autrepart. IRD: Paris, 5-16.

Kelly, R. L. (1992) 'Mobility/Sedentism: Concepts, Archaeological Measures, and Effects'. Annual Review of Anthropology 21: 43-66. 
Kent, M. (2008) 'The Making of Customary Territories: Social Change at the Intersection of State and Indigenous Territorial Politics on Lake Titicaca, Peru'. The Journal of Latin American and Caribbean Anthropology 13(2): 283-310.

Le Tourneau, F.-M. (2008) 'Stratégies territoriales amérindiennes dans un contexte pluri-ethnique: la région de Auaris (Roraima)'. Confins 3. [WWW document]. URL http://confins.revues.org/3653 [accessed 4 March 2013].

$\mathrm{Lu}, \mathrm{F}$. (2007) 'Integration into the Market among Indigenous Peoples: A Cross-Cultural Perspective from the Ecuadorian Amazon'. Current Anthropology 48(4): 593-602.

McSweeney, K. and Arps, S. (2005) 'A 'Demographic Turnaround': The Rapid Growth of the Indigenous Populations in Lowland Latin America'. Latin American Research Review 40(1): 3-29.

McSweeney, K. and Jokisch, B. (2007) 'Beyond Rainforests: Urbanisation and Emigration among Lowland Indigenous Societies in Latin America'. Bulletin of Latin American Research 26(2): 159-180.

Newing, H. S. (2009) 'Unpicking 'Community' in Community Conservation: Implications of Changing Settlement Patterns and Individual Mobility for the Tamshiyacu Tahuayo Communal Reserve, Peru' in M. N. Alexiades (ed.) Mobility and Migration in Indigenous Amazonia: Contemporary Ethnoecological Perspectives, Studies in Environmental Anthropology and Ethnobiology. Berghahn Books: Oxford, 97-114.

Ostrom, E. (1990) Governing the Commons: The Evolution of Institutions for Collective Action. Cambridge University Press: Cambridge.

Sirén, A. (2007) 'Population Growth and Land Use Intensification in a Subsistence-Based Indigenous Community in the Amazon'. Human Ecology 35(6): 669-680.

Tilkin Gallois, D. (2004) 'Terras occupadas? Territorios? Territorialidades?' in F. Ricardo (ed.) Terras indigenas et unidades de conservaçao da natureza. O desafio das sobreposições territoriais. ISA: Sao Paulo, 37-41.

Tiouka, A. and Karpe, P. (1998) 'Droits des peuples autochtones à la terre et au patrimoine'. Journal d'Agriculture Traditionnelle et de Botanique Appliquée 40(1-2): 611-632.

Torre, A. and Zuindeau, B. (2009) 'Proximity Economics and Environment: Assessment and Prospects'. Journal of Environmental Planning and Management 52(1): 1-24.

Tritsch, I. (2013) Dynamiques territoriales et revendications identitaires des Amérindiens Wayãpi et Teko de la commune de Camopi (Guyane française). Doctoral thesis, Université des Antilles et de la Guyane, Cayenne, French Guiana.

Tritsch, I., Gond, V., Oszwald, J., Davy, D. and Grenand, P. (2012) 'Dynamiques territoriales des amérindiens wayãpi et teko du moyen Oyapock, Camopi, Guyane française'. Bois et Forêts des Tropiques 311(1): 49-61. 